\title{
Labour Market Demands, Employability and Authenticity
}

\author{
Minna Nikunen ${ }^{1}$
}

Received: 3 March 2021 / Revised: 14 June 2021 / Accepted: 14 June 2021 /

Published online: 21 July 2021

C) The Author(s) 2021

\begin{abstract}
Finding employment has been a challenge for young adults in recent years. This is not only due to high unemployment rates, but also because entering working life is more complicated than before. It is no longer just a question of credentials and skills. 'Employability' depends on investments in personal capacities: labour market demands in recruitment exceed the capacity of employees' bodies and minds. This article asks what demands for increasing one's employability young adults (aged 18-30) experience in relation to their education and working life and how they respond to these ideas, especially to the idea of modifying their minds and bodies-habitus - in order to increase their employability. What demands are they complying with or resisting? How and why are they doing so? The article draws on interviews with 40 young Finnish women and men. The data analysis reveals that employability ideals emphasising affective and bodily capacities or dispositions are not shared by everyone. However, modifying one's attitude or demeanour seems to be less threatening for young adults than does changing one's appearance or body. Changes to one's body are associated with rules and codes dictated from above, whereas changing one's mindset is usually conceived of as self-development; thus, it is not seen as contrary to authenticity. Identification with a line of work is an important factor in accepting demands on one's body or demeanour. It should be asked if the importance of authenticity for young adults entering working life should be taken into consideration in governmental youth and employment policies.
\end{abstract}

Keywords Employability $\cdot$ Young adults $\cdot$ Affective labour $\cdot$ Authenticity $\cdot$ Habitus

Minna Nikunen

Minna.m.nikunen@jyu.fi

1 Department of Social Sciences and Philosophy, University of Jyväskylä, Jyväskylä, Finland 


\section{Introduction: Employability}

Investing in one's bodily and mental capacities for the sake of working life: is this the current zeitgeist, a shared attitude among policymakers as well as young people? Recent theory and research regarding changes in working life claim that affective and bodily demands have become more pronounced than ever (e.g. Adkins 2016). In this article, I investigate how and why, that is, on which grounds, young adults modify or refuse to modify their minds and bodies in order to increase their employability. I focus specifically on how they recognise and talk about these demands in relation to employment and recruitment rather than as part of working practices. In my analysis, I will trace interviewees' ideas of the demands they face (employability) and their ideas about the meaningfulness of these demands for themselves (identity). The analysis in this paper is sensitive to the gendered aspects of 'employability' and habitus.

Investing in oneself and increasing one's employability are seen as important, since competition for scarce resources, such as decent employment, has become fiercer (e.g. Brown 2013, 687; Stahl et al. 2017). As it is in other EU countries, youth unemployment is an enduring problem in Finland. In the case of young people, being active and getting onto the fast track to education and then employment is presented as essential, at least in vocational education (e.g. Vanttaja 2012). However, this is not always enough: one has to compete with an impressive $\mathrm{CV}$ and develop other required capacities. Employability - as emphasised in individualised education and work policies in Finland and other EU countries-is not only about credentials and skills (Harvey 2001; Morley 2001; Adkins 2016).

The term 'employability' gives the impression that employment depends on the individual and their willingness (or lack of it) to develop their capacities in and out of education. Spohrer (2011, p. 54) suggests 'employability can be regarded as [a] strategy aimed at increasing people's readiness to acquire the qualities that are needed in the labour market' in education and elsewhere. While 'employment' requires that an employee with the right skills and qualifications finds a job, 'employability' means being able to show one's potential to be successful in the job (Morley 2001). This potential is not gained directly from education, but is affected by other activities and capacities, which can be related to gender, social background, age or physical appearance (e.g. Harvey 2001). Additionally, Brown et al. (2003, p. 110) argue that 'employability is primarily defined by the labour market rather than by capacities of individuals'. Thus, employability is a way to talk about employment that stresses young people's responsibilities. Young people are educated and advised to increase their employability by acquiring credentials and skills and, more importantly, by improving themselves through obtaining valued experiences and capacities (Harvey 2001; Morley 2001; Nikunen 2017). In Lisa Adkins's (2016, p. 4) words: 'the prudent employee and would-be employee should continuously invest in their bodily and affective states to ensure future employability'.

The emphasis on employability and potentiality - expected success in work (e.g. Morley 2001) - has sometimes been connected to the new demands of working life, especially in the global North and so-called Western societies. This emphasis is coherent with the growing influence of neoliberal ideologies 
on EU and national policies, which have emerged in Finland especially after the global economic crisis of 2008 (Nikunen 2017; Ikonen and Nikunen 2019). The term 'new work' has been used to highlight the idea that in the new economy - the post-Fordist economy or late modernity-workers must be selfprogrammable, and unskilled generic workers are no longer needed (Castels 2000; McDowell 2008). On the general level, it is claimed that work requires self-reflexivity and mobility in terms of performativity. Mobility and reflectivity of the self are essential both in taking up new 'opportunities' and being capable of the performances needed in work (Adkins 2002).

However, not all work has changed, and there is much continuity as well (McDowell 2008). In Finland, the proportion of manual workers has declined and the proportion of non-manual employees in the workforce has increased since the 1960s, and after the financial crises of the 1990s, heavy industries gave way to knowledge-intensive sectors. Nevertheless, there is still a considerable amount of manual and industrial jobs (Lahtinen et al. 2020, p. 307), though technology and digital tools are firmly part of them (Honkatukia and Lähde 2020). In Finnish job advertisements, there is a clear difference between blue-collar and white-collar work: 'the abilities required of bluecollar employees' are 'considerably fewer than those demanded of white-collar employees', even though blue-collar workers were now expected readily to be able to collaborate have a good attitude towards customer service and flexibility. Yet, as stated by Kuokkanen et al. (2013), 'there were still many blue-collar job advertisements with no or very few requirements other than proficiency' (p. 221). The job advertisements allegedly give some hint about the expectations - though it is not likely that the ideas young adults hold are based on them directly.

Even the policies that address youth and working life do not rely solely on the ideas of self-directness or self-reflectivity (alleged ideals of 'new work'). There are policies directed at supporting youth employability, such as entrepreneurial education in the national curriculum and financial support for international mobility (e.g. Korhonen et al. 2012; Nikunen 2017).

However, there are also policies directed at governing youth, such as activation policies, including employability coaching, backed by financial deterrents, and recently introduced time limits of state support for the student allowance (e.g. Vanttaja 2012; Adkins and Ylöstalo and Adkins 2020; Ikonen 2020).

\section{Demands, Identity and Habitus}

The demands mentioned above - reflected here using the concept of employability - are internalised, resisted or cast aside as irrelevant. These responses can be approached as a question of identity and identification and the joy derived from identifications. In this paper, I am relying on Bourdieu and Bourdieuian researchers on the questions of identity, but I also want to emphasise the joy factor by borrowing ideas from affective labour theorisations.

An essential question is does a person interpret that complying with employability demands is important or meaningful for one's future, bearing in mind that person's idea of an authentic self. Identification is a question of fitting in and wanting to fit in in a particular field; in other words: does one see that kind of future as worth investing in? It is a question if one is seen as fitting in or as lacking some required capacities - a system 
of dispositions - as well as a question of wanting to fit in with the field in question. ${ }^{1}$ Habitus refers to both a bodily and performative projection of the self: projections of its capacities (Illouz 2007). According to Bourdieu, those with a fitting habitus do not even feel that they are 'playing the game' demanded in a particular field. By dispositions, Bourdieu refers to the 'preposition, tendency, propensity or inclination of the body', especially (Bourdieu 1977, p. 214; see also Husu 2013, p. 3). Disposition can be seen as position taken towards the future (an action or investment).

In a similar vein, Alasuutari (2004, p. 132) states that 'making sense of one's role and position is not enough; people have to create a specific attitude and perspective (toward the subject position, i.e. a job) in order to tolerate the contextual conditions, maybe even finding pleasure and enjoyment from them' (see also Nikunen 2012). This resonates with the claim made by theorists of affective labour that identification and belonging relates to the joy that identification and networking brings to oneself (e.g. Thompson and Willmott 2016; Gregg 2010).

Affective labour theorists emphasise the emancipatory power of the labourer's affirmative feelings, such as love and desire (Hardt 2011; Karppi et al. 2016; Kolehmainen and Mäkinen 2019). According to these theorists, while such affects have the potential to free a person from the capitalist system, they are also a requirement for employability and for securing a job in the future (Gill and Pratt 2008; Gregg 2010). The pleasure one gets from one's work is important, and this is related to the joy of working - joy in one's achievements and the products of one's labour as well as in connecting with others (Gregg 2010).

The joy derived from work and the connections it provides also depends on whether the worker has or has not invested in their occupational position. According to Thompson and Willmott (2016) analysis of organisational engagement, identifications and related practices give pleasure - a jouissance associated with fantasies of identity. These affective self-investments and affectively driven identifications are derived from the available moral grammars (Thompson and Willmott 2016). Moreover, I would add that identification with the qualities and identities that are valued in one's line of work is important, because it gives pleasure and confidence. However, this identification might not be equally easy or self-evident for everyone. Fitting in may depend on one's gender or class position (Farrugia 2019b; Skeggs 2011). In Bourdieu's terms, one's habitus - cultural and bodily dispositions - affects the way one fits in as part of a field (of a certain occupation, for instance; Bourdieu 1990, p. 53: McNay 1999). The question is does one know how to play the game and does that person enjoy playing it. For some, the feel of the game is self-evident; others have to learn the rules. For the former group, identification with the position is therefore easier.

In that sense, joy is connected to the way how a position, role or identity connects to the idea of authenticity: 'The most profitable strategies are usually those produced on the hither side of all calculation and in the illusion of the most 'authentic' sincerity by a habitus objectively fitted to the objective structures' (Bourdieu 1977, p. 214; Husu 2013, p. 3). In organisation studies (Costas and Fleming 2009), it has been observed

\footnotetext{
${ }^{1}$ The word disposition seems particularly suited to express what is covered by the concept of habitus (defined as system of dispositions). It expresses first the result of an organising action, with a meaning close to that of words such as structure; it also designates a way of being, a habitual state (especially of the body) and, in particular, preposition, tendency, propensity or inclination (Bourdieu 1977, p. 214).
} 
that people want to preserve the sense of their 'true self' - although imagined - in organisational contexts that demand performing other kinds of identities. Authenticity can be found either in working life or outside of it.

However, even the authenticity of one's intimate life can be under threat because the corporate self takes over - there might not be enough time to perform the authentic self - or performing the corporate self requires deep acting, and thus blurs the sense of one's true self (see also Hochschild 1983). Feasibly, people in search of employment want to be employed in an occupation or a firm that provides opportunities to be themselves, where they are not required to be something else.

According to David Farrugia's (2019b) research on young people in search of employment, youth with a middle-class background accept the demands they recognise as reflecting their authentic self or a self that is in the process of becoming. Youth with a working-class background, on the other hand, recognise demands as something they have to compromise with and meet in order to get hired. Even self-realisation through work is understood differently by young people with working-class backgrounds than it is by those from the middle class. In the formulation that is seen as more typical for the middle class, passionate investments lead to personal growth - in line with official demandswhile for the working-class self-realisation means recognisable achievements and upward social mobility (Farrugia 2019a, p. 1087; see also Simola 2021; Ikonen 2020). For youth that identify with the working class, authenticity can mean being true to one's background (Reay 2002) and not being pretentious (Skeggs 2011). For instance, not imitating the middle class in its pretence of preferring immaterial values over material. It can also mean being true to one's (subcultural) youth identity (e.g. Tolonen 2013).

In my analysis of 40 interviews with young adults, I am interested in how the interviewees approach demands to develop their qualities: do they accept or resist them and why? However, change is not all that these theories are about; they also propose ideas about how people prepare for working life, how they use themselves - their bodies and affects - as tools for work, and their expectations of joy and self-fulfilment at work. Some of these aspects of working life may be recent; others have long histories, but have not previously received much attention. They therefore provide new perspectives on workers' and would-be workers' expectations and experiences of working life, which are useful for this study.

\section{Materials and Analysis}

I use interview materials gathered by our project on young adults' relation to working life and their expectations for the future - that targeted inequalities among the group as data. We interviewed 40 young adults (aged 18-30) from the Tampere region (Pirkanmaa) in 2015 and 2016. Tampere is the third largest city in Finland, with about 250,000 inhabitants, and it is the only big city in the area. The unemployment rate in the region was high at the time of the interviews, at about 18\% (Statistics Finland 2016), while in Finland, the unemployment rate was only $8 \%$. In Finland, the unemployment rate of youth aged 16 to 24 was $20 \%$ in 2016 (of those belonging to the active work force), and for youth aged 25 to 34, it was 9\% (Statistics Finland 2016). ${ }^{2}$ Many of

\footnotetext{
${ }^{2}$ Age-specific information is not available from Pirkanmaa.
} 
our interviewees had moved to Tampere from other parts of the country, since the city has many educational opportunities. The Tampere region is a good example of an area that attracts people from around the country. The region's good education opportunities, such as a university and universities of applied sciences (polytechnics), are especially attractive for young people (migration researcher Timo Aro: figures from Statistics Finland on population and migration, Rautanen 2017).

We sought participants from a variety of social networks, using email lists and contact persons from different organisations. Some respondents were targeted by the Youth Guarantee or supporting institutions; some were geographically mobile international students; some were actual or would-be start-up entrepreneurs; some were working; and some were out of work. The idea was to reach young people in different positions in relation to employment and working life. Only three of the interviewees had immigrated to Finland, one of whom had a Finnish mother. The percentage of the population with an immigrant background in Tampere is only $4.6 \%$, and in Finland overall, it is $4 \%$ (Family Federation of Finland 2016). Young women were keener to participate than men were, and hence, the gender ratio was 28:12.

The majority of the interviewees had completed secondary education ( 28 out of 40 ); some of these had gone on to vocational schooling, and some were in youth workshops or other supportive activities. Young adults' class positions are fluid, so for the sake of this analysis, I used mainly educational-level positions, interpreting 'middle class' as referring to those in higher education (including polytechnics) or in employment with higher education qualifications. However, for the sake of more detailed class analysis, it is possible to divide interviewees into middle class and working class according to their family background, their current position in education or working life, and cultural capacities, such as hobbies (Ikonen 2020).

In my analysis, I concentrate on interviewees' talk about (1) the demands young people face in employment and work, (2) their hopes and fears about the future and work, (3) their ways of coping with these demands and fears, and of realising their hopes. I started by identifying the answers about demands that the young people have encountered or noticed. Then, I divided these demands into different groups, according to the identified source of the demands (power structure) and the positioning young adults took in relation to these demands.

According to Johansson (2017), young people position themselves against existing power structures in their identity formations. This also applies to more situated positionings, such as identities (self-categorisations) constructed in an interview. This positioning can be either compliant or resistant in relation to the power structures to which the interviewee is oriented during the interview. In line with Bourdieu, I also track habitus - bodily and mental (cultural) dispositions taken — and the field they fit in. We asked young adults about the external pressures, norms and expectations they anticipated or had experienced in working life. This kind of question calls on interviewees to position themselves in relation to the power structures they have experienced.

In what follows, I analyse the ways interviewees positioned themselves against the demands young people face in working life. The analysis is an adaptation of discourse analysis positioning and self-categorisations (Potter and Wetherell 1987; Johansson 2017). The analysis is based on questions about demands in general, as well as questions about gendered demands in particular: do the interviewees think there are 
different expectations depending on whether one is a woman or a man? In the conclusion, I consider young people's compliance and resistance to the ideal of improving oneself in order to be employable.

\section{Results}

In the preliminary analysis, it seemed that young people-oriented to working life with more traditional attitudes and values than we had anticipated. The employability ideals of the new economy were not frequently mentioned - at least, not explicitly - when young adults talked about the demands they themselves faced in employment. However, demands and external pressures were registered. As already discussed, demands as external pressures can be approached in resistant ways. It is possible to interpret the interviewees as positioning themselves through their identity work in relation to existing power structures (Johansson 2017).

I present these positionings in three sections: those who present themselves as not affected by general expectations; those who acknowledge that these expectations affect their lives; and those answers that make the position directly in relation to the expectations of an employer or recruiters. In this third group, expectations relating to embodiment and behaviour emerge.

\section{Am not Affected-on the Self-Directed Path}

It was quite popular to position oneself as outside or above the game. We asked if interviewees felt any pressures or demands relating to education and working life. In these types of answers, pressures were usually presented in an abstract way: as expectations coming from outside.

Q: So you see that there are such pressures, but how do you succeed in not caring about them?

A: I don't conceive of myself as succeeding, because I have not even tried to be detached about them. I just am. I just live according to my own ideology. Q: And that is?

A: How should I put it? I just am sort of happy. Since I am sort of spiritually oriented [to life] - if you can say so. For me, it is important that I am happy on the inside, and not that some people look at me from the outside and say, 'oh, that person has succeeded since she is there and studies that or has that kind of occupation and gets such a salary'. (extract 1, woman, 21, university student)

In a way, the interviewees were saying I do not feel pressure, although others do-I am authentic and autonomous. However, in denying they do not play the 'common' game, they set up a different game altogether.

This discourse presented a continuum ranging from firm denial of compliance with assumed common values and goals to denial of being compliant on the grounds that one was meeting those expectations of their own accord. These shared values and goals were often expressed in an abstract way, but it is safe to say they refer to material 
success in work and conventional life. These interviewees positioned themselves as young people above or outside common expectations. Other people's values and demands do not affect them. They follow their own path, which may or may not be 'successful' in the eyes of others. In the above quotation, a university student does not care if others view her as successful because of her studies, occupation or salary. However, not playing the common game does mean playing the game of self-directness and displaying suitable habitus for that. In other words, it is the game played in the same field of employability as the 'commons' do but in a more sophisticated and allegedly more successful way. The employability is more of an affective state or disposition than a mark on a $\mathrm{CV}$. In others, the indifference may stem from different ways to conceive of success or life goals. In the next extract, for example, a young man interested in music states that the most successful thing in life would be 'underground success', not mainstream success.

Furthermore, there are significant differences between the two ends of the continuum: those who emphasise happiness (in extract 1) and those who concentrate concretely on another path, such as music (see extract 2). The former are often also interested in career success but not because of others' expectations. Instead, they strive only for their own happiness and self-fulfilment, as we have discussed in more detail in another article (see Nikunen and Korvajärvi 2020). The latter may see success as a distinct possibility - they are on a countercultural or subcultural success path. (The former group consists mainly of women in higher education while the latter men with a high school diploma or only basic education.)

Well, I don't think that these [demands] affect me because I think so differently about things, and that depends on the person. Those who are more mainstream are more likely to be affected. My thinking is quite different and sort of marginal. (...) There are people who look for, from their life, look for an occupation after education, and then dating and then marriage and then starting a family [with children]. Those people who - want to get ahead in their career - they think about these [demands] but I do not see things like that at all. (extract 2, man 21, vocational diploma, youth workshop)

The interviewee does not want to play the 'mainstream' game that career-oriented people play. However, he would like to have success in the field of independent music, being rewarded according to the rules of that field. He is showing the right habitual disposition, including the tendency to avoid 'selling out'. Compromising with mainstream music or a common life is not a possible move in the field of counterculture(s), though employment strictly for money or an unemployment benefit may be accepted as means of survival. (On marginality and authenticity e.g. Müller 2016, pp. 11-12.)

These latter answers, which emphasise individuality and authenticity, reflect the fact that there are future plans that are not in line with shared expectations. The formeremphasising one's own internal happiness, self-reliance and self-directedness - are actually in line with neoliberal ideas of the working subject. In both cases, cultural or countercultural games have become internalised and thus feel as if they are 'coming from inside'. Others who conform serve as a mirror in which one's own autonomy and authenticity is reflected, and in many cases, the passion towards what one wants to do. 
Employability, such as improving one's CV, is for others - or it is not central in one's future success. Instead, success will come with the right attitude and following one's own path.

\section{Society's Expectations Have an Influence}

Some acknowledged they experienced pressure and there was something that society and others expected of them. In describing these expectations, this group was in line with the former, no-pressures group. 'Society' expects young people to either have a job or receive an education. It expects young adults to transition quickly from youth through education to work. For some, it expects them to live conventional lives, marry and have children. These expectations of society were usually mediated to young people through the media, educational and other institutions, parents and other people in general. 'Other people' seem mainly to expect compliance with norms. The position taken in relation to these expectations was not as sharply above or outside as they were in the former group, and thus representatives of this group were able to express criticism towards those who set these expectations, not only those who comply with them. The members of this group are willing or feel forced to play the game of employability_just like all the other young people or students.

Expectations were not treated as something coming from working life but more like general ideas of how young people should behave or work their way towards working life. They positioned themselves as representatives of young people, as students or as citizens. The answers were not particularly personal, but problems concern who the participants referred to as 'you', in other words, all the young people. This was a position that allowed a critical and collective stance towards expectations. Interviewees mentioned pressures to complete their studies in a short time and find employment and demands to be flexible and resilient in order to ensure employment and to be competitive in getting a job (see also Ikonen and Nikunen 2019).

It is sometimes really stressful, because there are many things [required], that you should get an education and you should get working, soon. [Interviewer: So you are expected to be swift in that process?] Yes, and in graduating. And everything, if you just follow the media and what they are talking about, that student allowance will be for a shorter period, and everything should be really efficient and fast. That is really stressful, also because you don't yourself know what you want to do in the future. Even though you have plans, they can change or something. (extract 3, woman, 21, polytechnic diploma, supported employment)

There are quite a few [expectations] or in a way you cannot be calm and peaceful and think that I can calmly be the sort of person I am. Perhaps something... in this current situation people do not necessarily know what working life will be in 20 years, so maybe that affects the way people speak about it. Then you have to be a person with multiple skills and be able to do this and that. That is - at least on the discursive level-it's gotten out of hand so that you have to be so much in every way. Additionally, I do not like the pressure around graduation that you should do it in five years. I understand that it is the ideal, but I myself have altered my plans, so I think it is better that people are given time and opportunities, and 
perhaps support for internships, so one could decide what the right thing is for oneself. (extract 4, woman 20, university student)

On the one hand, they criticise the concrete demands (they face) made by the politicians, especially policies on the fast track form of study to work (a version of work-first policy). On the other hand, they also see the demands that relate more to the discursive and historical context. This includes society and the current state of competition and related insecurities as well as the expectations that one should develop skills needed in future work that are impossible to anticipate. One could also sense an identification of a student to the subjects studied at university or political identification. These demands do not relate to employability as such but more to demands on mental capacities in life, being flexible and resilient.

\section{Employers' Demands Affect Also Me but Mainly Others}

Our main aim when asking questions about expectations was to address demands in employment and working life and recruitment. Indeed, what it takes to enter working life and stay there was the focus of many answers. In these answers, demands were clearly interpreted as demands on employability. This question was often approached from a larger perspective than one's odds of getting hired: in the search for employment, one has to be patient and resilient. You have to be flexible, because that is the expectation, and because flexibility also benefits your employer and ensures your future employment. These affective skills are required to adjust to the precariousness of working life (e.g. Hardt and Negri 2000). Additionally, there were expectations concerning skills, experience, credentials, behaviour and bodily performances: the actual core of 'employability'.

Employers' overvaluation of work experience was seen as the main obstacle to young people finding employment. This was a source of explicit criticism: no one can have work experience before they are hired for the first time. Employers expect too much. This discourse positioned interviewees as would-be workers in the context of new work, emphasising precariousness and employers' position as selectors-winners in the game where the scarcity of jobs makes contestants compete against each other (e.g. Brown 2013, 687; Stahl et al. 2017). In this context, young people require flexibility and resilience.

Expectations regarding skills — other than soft or affective labour skills — were rarely mentioned. Some mentioned vaguely that being multi-skilled was expected. One interviewee, a man, coder 27 (also extract 10), mentioned 'that a skilled guy will not end up out of work [in their line of work]'. He is not worried about his future in working life. The notion seemed to prevail that personality, personal features and attitudes were more important for employment and work than acquired skills and knowledge were. Demands, therefore, have the potential to affect identity and be a boost or a threat to authenticity and one's true self. Indeed, behaviour and demeanour were perceived as important. This was often a traditional combination of being honest, hardworking and reliable, obeying orders, fulfilling duties and being polite and friendly to other employees and customers. They are playing the game in the fields of blue and pink collar (service and care sector) jobs. The more recent discourse emphasising personality, self-assurance, imitativeness and (self-)presentation skills-presenting 
oneself as autonomous in a way that emphasises self-control and suitability as a subject (McNay 2009; Ikonen and Nikunen 2019)—was also widely used.

Q: What kind of person do you think is one who is successful?

A: The sort of person that gets along with everyone. You should not be too arrogant, but you should not be too sort of shy or submissive or like that, you know. That you have to be someone who gets along with others and is a likeable person. And the, I believe in a positive attitude, you have to be sort of positive as well.

Q: Positive. How about those who are socially marginalised? How do you see them?

A: Margin - It is that you might be afraid of being with other people or are afraid, you do not dare to do things. Yes, that kind of. Someone who has no courage. (extract 5, woman, 27, master's degree, part-time entrepreneur/consultant)

'Getting along with everyone' sounds traditional here, though enjoyment derived from networking and connecting with others are still important aspects of affective labour (Gregg 2010; Thompson and Willmott 2016). Employability depends on being selfconfident and a social team player. This is showing the right mental habitus which fits in the field. Positive attitude, optimism and happiness were also presented as important mental capacities in finding employment and being successful (Nikunen and Korvajärvi 2020).

The ideas that one should adapt one's bodily appearance were not as popular as adapting one's behaviour or personality. This was approached as a question of authenticity related to youth culture:

Especially, in my opinion, there is one thing that employers should understand, have black hair, and that is quite okay. It is so conservative [old-fashioned] if it affects anything nowadays. Though I understand it then if it is a question of hygiene [e.g. in nursing]. (extract 6, man, 21, upper secondary school, youth workshop)

Conservative, old-fashioned ideas are not reasonable, but in certain cases, such as for hygiene-related reasons, demands about one's appearance are fair. Authenticity is part of one's private life, but an employer's rules about one's habitus-hair-colour, piercing, tattoos - often extend beyond the realm of the work. When the clothes are part of a uniform and taken off when one goes home, it is not a threat to authenticity. The same goes for demeanour when it is only a performance of a mindset: in some lines of work, you can shake it off just like the uniform. It relates to the habitual disposition to play the games of the countercultural or youth cultural field that the rules of 'common' working life seem to interfere with. Furthermore, these working life rules are resisted: they are made invisible as rules set by the 'others' and that are not practical but only customary.

The demands on one's body were often seen as something that does not concern oneself but 'others', such as those with a lower educational level, women or those in other lines of work. 
I think that those pressures about appearance or expectations, they are in earlier stages - or not earlier but in other occupations. Especially on the vocational level and such. (extract 7, man, 27, university student)

Q: Do you think that people expect different things from women and men?

A: Well, sure. Not consciously, but I believe that, at least when you think about office work, people expect that women have prepared themselves or that they are presentable if they are in contact with people and on display. But I don't know about carpentry, I don't believe it is so-I suppose it is more like a disadvantage if you would really try to be that way. (extract 8, woman, 27, degree in crafts, secondary general academic diploma)

While 'others' in the group that emphasised self-directedness were just those who want to follow the common path and comply with norms, in this group, 'others' were more clearly bodily or affective performances. 'Others' were seen as playing the game in their field that required a habitus others had coded for them. For instance, women can be seen as using their bodily capacities and reflecting a required affectual state in the game of pleasing the customers (see Hochschild 1983).

Masculine demands were less easily grasped than feminine demands were. Talk about the body and appearance is sometimes perceived as a sensitive subject in interviews (Pullen and Rhodes 2008). In order to open up this topic for discussion, we told one male interviewee about a study showing that today's executives had to look fit and lean (Tienari and Meriläinen 2016). The interviewee then found a way to express his own thoughts on the subject:

A: Certainly there is. If the organisation is successful, then you have greater pressures to look as if you are successful, I presume.

Q: So, do you think that in your profession, in the area of expertise that you are interested in, are there certain behavioural or...

A: Yes, I think there is. I suppose that you just have to find there that other side, that no... I think that a black suit and collared shirt every day is not necessarily my thing. So then, you just have to get the kind of position where you get along by doing less. (extract 9 , man, 28 , university student)

This interviewee's friend had a year's internship with the United Nations in New York and had to wear a suit all the time. Based on that reason, the interviewee concluded the United Nations was not the place for him. Furthermore, he stressed that a suit was not the core or essence of work. The suit-and-tie combination was almost the only such demand placed on men, but this young man wanted to avoid even that. The suit was not only a uniform but also a matter of demeanour: having pressures to look successful is contrasted with being authentic.

As stated previously, many interviewees saw demands as concerning mainly others, including other men but also other lines of work:

I think that depends on the profession. In marketing, for instance, you notice that people there pay more attention to their appearance. Then, in the coding business, 
it is sort of a joke that everybody else is dressed in suits, and the coder comes in wearing a t-shirt. (extract 10, man, 27 , polytechnic education, coder)

In this extract, the way coders are presented is more interesting than the attention marketing people are said to pay to their appearance. The way marketing people dress is presented as coded, but the way programmers dress is seen as freedom and authenticity. The game feels natural, easy to play and therefore authentic. Even though outsiders may conceive that coders follow some code in their appearance, for the insider, it just indicates freedom. Among the interviewees, those who were ready to comply with bodily expectations saw them as 'natural'. They were not seen as set outside or above but linked with professional identity.

In a way, demands on mental capacities were perceived to be more reasonable and less threatening for authenticity than expectations for one's body were. Actually, when mental demands were seen as requirements set from the outside, they were connected to bodily habitus. The cases when dressing like others gives one joy and not discomfort are therefore noteworthy: this happens when one identifies with one's occupation.

\section{Conclusions}

For many young adults, the demands of working life did not seem overwhelming. The demands on one's appearance and for a good attitude were accepted if they were reasonable, if they somehow 'made sense'. For them, the key to success in the world of work is simply to be honest and hardworking: this was common among younger adults and/or those with a lower educational level. Employability is a matter of attitude in work. The employers' demand for working experience was acknowledged widely but regarded as unfair. This was a shared opinion across genders and educational levels. Other observations included the precarious position of young employees in the competitive world of new work and the resilience it requires.

Alongside talk about being hardworking, nicely behaved and having work experience, there were also reflections on novel ideas of employability. Demands to adjust one's bodily appearance - for reasons other than practical ones-were accepted by only a minority, but the existence of such demands was acknowledged by the majority, albeit in a distancing and sometimes even hierarchy-building way (e.g. hierarchies of gender, class, (sub)culture and occupation). Bodily demands were seen as involving only some occupations - other than one's own or aspired occupation - or primarily women. These demands obviously violated the widespread goal of being self-directed and authentic (e.g. McNay 2009). This was the case because demands were often conceived as orders and rules that related to those lower in the hierarchy, with a lower education. However, for those who had found an occupation they identified with, such demands sounded reasonable, or were not regarded as demands at all. If one is playing the game in the field you are a part of, following the rules feels authentic.

Affective demands can be conceived as pressures to display the right attitude. The right attitude might be modesty, carefulness or respectfulness, which resemble old-style views of employee-employer relations. It could also include innovation, optimism, entrepreneurialism or happiness, which are more in line with ideas about new work, acquiring affective capacities and heightening employability (e.g. Adkins 2016; Nikunen and Korvajärvi 
2020; Ikonen and Nikunen 2019). It seems it is easier to think about adopting the right attitude than it is to consider changing one's appearance to please others. Having a sort of affective makeover - taking one affect, such as positivity or happiness, as a guide to life and employability — was taken seriously, mainly by young women studying or educated in universities who can be interpreted as representatives of the middle class (Nikunen and Korvajärvi 2020; also Gill 2017; Ikonen 2020).

In relation to demands associated with new work, changing one's bodily appearance raises more eyebrows than does cultivating affective skills and appearances: improving one's personality is a widely accepted goal. Modifying one's attitude or demeanour seems to be less threatening for young adults than changing one's appearance and body does. Mental changes can be associated with personal growth while changes of appearance are associated with acting out outside dictated norms. Changing one's looks is more about conforming to others' ideas unless it is seen as reasonable or in line with one's identity. Therefore, it is associated more with others in other occupations. Gender is also central. Women or other women in more feminine occupations are seen as using their bodily capacities. This use is sometimes even condemned and other times seen as a mark of a lower position in which one is obliged to act as an employer demands. The idea that bodies of women are an integral part of their work-habitus is thus used and confirmed in interviewees' presentation of their own habitus.

In conclusion, the question of demands was often approached in a critical and even distancing way, but also in ways that were practical and confirming or which sometimes even created pride. The practical approach included questions of what is needed and how can one develop. The critical approach asked if these demands are reasonable or fair. In distancing, the question was if compliance is threatening to one's authentic and autonomous self. The conforming way accepted an attitude of 'this is how it goes'. Pride (or admiration), though, requires that conforming is conceived as freedom and authenticity. The ideas seem to fall between old and new work, rather than being entirely on one side or the other (Kuokkanen et al. 2013; Nikunen 2017). For example, those aiming for an authentic self and resisting conformity can be either ones who find their passion in work or something outside work; thus, their work identity becomes only a means not an end. Young adults are not moulding their habitus, at least not in conscious ways, but more likely in ways that appeal to their sense of authenticity. From the policy point of view, it should be considered if it is good or functional to affirm demands that better suit some young people or some career paths more than others.

Funding Open access funding provided by University of Jyväskylä (JYU). This research was funded by the Kone Foundation.

\section{Declarations}

Conflict of Interest The author declares no competing interests.

Research Involving Human Participants The research was conducted by the ethical guidelines of the National Advisory Board on Research Integrity (Finland).

Informed Consent Informed consent was obtained from the participants. 
Open Access This article is licensed under a Creative Commons Attribution 4.0 International License, which permits use, sharing, adaptation, distribution and reproduction in any medium or format, as long as you give appropriate credit to the original author(s) and the source, provide a link to the Creative Commons licence, and indicate if changes were made. The images or other third party material in this article are included in the article's Creative Commons licence, unless indicated otherwise in a credit line to the material. If material is not included in the article's Creative Commons licence and your intended use is not permitted by statutory regulation or exceeds the permitted use, you will need to obtain permission directly from the copyright holder. To view a copy of this licence, visit http://creativecommons.org/licenses/by/4.0/.

\section{References}

Adkins L (2002) Revisions: gender \& sexuality in late modernity. Open University Press, Buckingham

Adkins L (2016) Contingent labour and rewriting of the sexual contract. In: Adkins L, Dever M (eds) The post-Fordist sexual contract: working and living in contingency. Palgrave Macmillan, Houndmills, pp 1-28

Alasuutari P (2004) Social theory and human reality. Sage, London

Bourdieu P (1977) Outline of theory of practice. Cambridge University Press, Cambridge

Bourdieu P (1990) The logic of practice. Stanford University Press, Stanford

Brown P (2013) Education, opportunity and the prospects for social mobility. Br J Sociol Educ 34(5-6):678-700

Brown P, Hesket A, Williams S (2003) Employability in a knowledge-driven economy. J Educ Work 16(2):107-126

Castels M (2000) The rise of the network society. Blackwell, Cambridge MA

Costas J, Fleming P (2009) Beyond dis-identification: a discursive approach to self-alienation in contemporary organizations. Hum Relat 62(3):353-378

Family Federation of Finland (2016) Maahanmuuttajien määrä. Retrieved from http://www.vaestoliitto.fi/ tieto_ja_tutkimus/vaestontutkimuslaitos/tilastoja/maahanmuuttajat/maahanmuuttajien-maara/

Farrugia D (2019a) Class and the post-Fordist work ethic: Subjects of passion and subjects of achievement in the work society. The Sociol Rev 67(5): 1086-1101

Farrugia D (2019b) The formation of young workers: the cultivation of the self as a subject of value to the contemporary labour force. Curr Sociol 67(1):47-63

Gill R (2017) The affective, cultural and psychic life of postfeminism: a postfeminist sensibility10 years on. Eur J Cult Stud 20(6):606-626

Gill R, Pratt A (2008) Precarity and cultural work: in the social factory? Immaterial labour, precariousness and cultural work. Theory Cult Soc 25(7-8):1-30

Gregg M (2010) Working with affect in the corporate university. In: Paasonen S, Liljeström M (eds) Working with affect in feminist readings: disturbing differences. Routledge, London, pp 182-193

Hardt M (2011) For love or money. Cult Anthropol 26(4):676-682

Hardt M, Negri A (2000) Empire. Harvard University Press, Cambridge, MA

Harvey L (2001) Defining and measuring employability. Qual High Educ 7(2):98-109

Hochschild AR (1983) The managed heart: commercialization of human feeling. University of California Press, Berkeley

Honkatukia P, Lähde M (2020) Navigating towards sustainable working life -young people imagining the technologised future of work. J Youth Stud 1-16. https://doi.org/10.1080/13676261.2020.1820971

Husu H-M (2013) Social movements and Bourdieu: class, embodiment and the politics of identity. University of Jyväskylä, Jyväskylä

Ikonen H-M (2020) Having a top-class mindset? Post-feminism and the co-construction of class and mindset among young Finnish women. Gender and Education 32(7):944-960. https://doi.org/10.1080/09540253. 2019.1632420

Ikonen H-M, Nikunen M (2019) Young adults and the tuning of the entrepreneurial mindset in neoliberal capitalism. J Youth Stud 22(6):824-838

Illouz E (2007) Cold intimacies: the making of emotional capitalism. Polity Press, Cambridge

Johansson T (2017) Youth studies in transition: theoretical explorations. Int Rev Sociol/Rev Inst Sociol 27(3): 510-524

Karppi T, Kähkönen L, Mannevuo M, Pajala M, Sihvonen T (2016) Affective capitalism: investments and investigations. Ephemera Theory \& Politics in Organization 16(4):1-13

Kolehmainen M, Mäkinen K (2019) Affective labour of creating atmospheres. Eur J Cult Stud 24:448-463. https://doi.org/10.1177/1367549419886021 
Korhonen M, Komulainen K, Räty H (2012) "Not everyone is cut out to be the entrepreneur type": how Finnish school teachers construct the meaning of entrepreneurship education and the related abilities of the pupils. Scand J Educ Res 56(1): 1-19

Kuokkanen A, Varje P, Väänänen A (2013) Transformation of the Finnish employee ideal in job advertisements from 1944 to 2009. Acta Sociol 56(3):213-226

Lahtinen H, Sirviö O, Martikainen P (2020) Social class and the risk of unemployment: trends, gender difference and the contribution of education. Acta Sociol 63(3):303-321

McDowell L (2008) The new economy, class condescension and caring labour: changing formations of class and gender. Nora 16(3):150-165

McNay L (1999) Gender, habitus and the field: Pierre Bourdieu and the limits of reflexivity. Theory Cult Soc 16(1):95-117

McNay L (2009) Self as enterprise. Dilemmas of control and resistance in Foucault's the birth of biopolitics. Theory Cult Soc 26(6):55-77

Morley L (2001) Producing new workers: quality, equality and employability in higher education. Qual High Educ 7(2):131-138

Müller T (2016) Saved by rock' n' roll: Lou Reed, his fans and the becoming of the (marginal) self. In: Scneider CJ, Kotarba J (eds) Symbolic Interactionist Takes on Music. Emerald Books, Bingley, pp 1-20

Nikunen M (2012) Individualization and identity work: coping with the 'entrepreneurial' university. In: Ahola S, Hoffman D (eds) Higher education research in Finland - emerging structures and contemporary issues. Third yearbook of higher education research. Consortium of higher education researchers in Finland (CHERIF), Jyväskylä, pp 271-289

Nikunen M (2017) Young people, future hopes and concerns in Finland and the European Union: classed and gendered expectations in policy documents. J Youth Stud 20(6):661-676

Nikunen M, Korvajärvi P (2020) Being positive, being hopeful, being happy: young adults reflecting on their future in times of austerity. Eur J Cult Stud OnlineFirst 1-19. https://doi.org/10.1177/1367549420935901

Potter J, Wetherell M (1987) Discourse and social psychology: beyond attitudes and behaviour. Sage, London

Pullen A, Rhodes C (2008) Dirty writing. Cult Organ 14(3):241-259

Rautanen S (2017) Tampereelle muuttaa enemmän työttömiä kuin työssä käyviä: 'kasvu on ollut huimaa' [people moving to Tampere are more often unemployed than employed. 'Increase is huge']. Aamulehti, 13 January 2017. Retrieved from https://www.aamulehti.fi/kotimaa/tampereelle-muuttaa-enemmantyottomia-kuin-tyossa-kayvia-kasvu-on-ollut-huimaa-24201368

Reay D (2002) Class, authenticity and the transition to higher education for mature students. Sociol Rev 50(3): $398-418$

Simola A (2021) Passionate EU citizens or precarious migrant workers? Young EU migrants, neoliberal governance and inequality within the free movement regime. University of Helsinki, Helsinki

Skeggs B (2011) Imagining personhood differently: person value and autonomist working-class value practices. Sociol Rev 59(3):496-513

Spohrer K (2011) Deconstructing 'aspiration': UK policy debates and European policy trends. Eur Educ Res J 10(1):53-63

Stahl G, Nelson JD, Wallace DO (2017) Introduction. In: Stahl G, Nelson JD, Wallace DO (eds) Masculinity and aspiration in the era of neoliberal education. Routledge, New York, pp 1-16

Thompson M, Willmott H (2016) The social potency of affect: identification and power in the immanent structuring practice. Hum Relat 69(2):483-506

Tienari J, Meriläinen S (2016) Palvelukseen halutaan ajokoira: johtajan ulkonäkö ja esiintyminen. Helsinki, Kustannusosakeyhtiö Siltala

Tolonen T (2013) Youth cultures, lifestyles and social class in Finnish contexts. Young 21(1):55-75

Vanttaja M (2012) Opiskelijoiden työssäkäynti ja opintojen pitkittymisen ongelma. Suomen kasvatustieteellinen aikakauskirja 43(3):291-297

Ylöstalo H, Adkins L (2020) Economizing the political: workfare reform in strategic management mode. Current Sociology OnlineFirst 1-19 https://doi.org/10.1177/0011392120913579 